\title{
Analisis Kebutuhan Konsumen Hotel Savero Dengan Metode Quality Function Deployment (QFD)
}

\author{
Sofiani ${ }^{\mathrm{a}, 1}$, \\ ${ }^{a}$ Prodi Hospitality dan Pariwisata - Universitas Bunda Mulia Jakarta \\ ${ }^{1}$ sofiani@bundamulia.ac.id
}

This research was conducted to see the needs of hotel consumers by using the Quality Function Deployment (QFD) method at Hotel Savero. The purpose of using $Q F D$ in this study is to see consumer needs (customer needs) and corrective action (technical characteristics). In addition, indicators of consumer perceptions and perceptions as well as the gap between expectations and consumer perceptions and whether there are significant differences between expectations and perceptions. The data were processed using Quality Function Deployment (QFD. The results showed that there was a negative gap between expectations and perceptions as well as a significant difference between expectations and consumer perceptions.

\section{Pendahuluan}

\subsection{Latar Belakang}

Banyaknya hotel yang bermunculan jelas berdampak pada semakin ketatnya persaingan bisnis dalam industri ini.Dengan semakin ketatnya persaingan bisnis perhotelan ini, pihak perusahaan diharuskan untuk meningkatkan kualitas pelayanan agar bisa terus bertahan di dunia bisnis (Sholeh, 2013). Suara konsumen (voice of costumers) dapat di dengarkan pihak hotel dengan menggunakan metode Quality Function Deployment (QFD) (Bramson, 2004).

Untuk menerjemahkan suara pelanggan kita dapat menggunakan metode Quality Function Deployment (QFD). Dengan menggunakan Quality Function Deployment, perusahaan dapat mengetahui apa yang dibutuhkan oleh konsumen, dapat memperbaiki dan meningkatkan kualitas layanan perusahaan sehingga konsumen merasakan kepuasan terhadap layanan perusahaan tersebut. Guna mengidentifikasi dan memenuhi kebutuhan serta keinginan konsumen, kemudian mengkonversikannya ke dalam strategi yang tepat serta produk dan proses yang dibutuhkan perusahaan dapat menggunakan QFD. Harapan-harapan dari konsumen yang spesifik menjadi arah perencanaan strategik dan tindakan teknik.

Tindakan-tindakan teknik yang dilakukan dalam Quality Function Deployment (QFD) meliputi empat proses utama, yaitu product planning, design planning, process planning dan production planning (Fanani, 2008). Proses yang memudahkan perusahaan untuk mewujukan keinginan konsumen dengan terstruktur dan sistematis.

Dengan semakin banyaknya hotel baru bermunculan mengakibatkan tingginya persaingan di industri perhotelan. Hal ini mengakibatkan menurunya tingkat hunian di Hotel Savero. Guna meningkatkan kembali tingkat hunian perlu di lakukan penelitian mengenai hal apa saja yang dibutuhkan konsumen (customer requirements) terhadap Hotel Savero dan untuk mengetahui apa yang bisa dilakukan (technical characteristics) oleh Hotel Savero untuk memenuhi kebutuhan konsumen.

Jaringan Savero Hotels meramaikan kawasan Depok dengan membuka Hotel Savero Depok. Mengusung konsep serupa dengan Grand Savero Bogor yakni mewah dan elegan hotel bintang tiga 
ini menawarkan 108 kamar bertipe Superior, Deluxe, dan Suite. Hotel yang terdiri dari 10 lantai ini dilengkapi pula dengan fasilitas seperti restoran, pusat kebugaran dan spa. Sementara bagi pelancong bisnis, Hotel Savero Depok menyediakan enam ruang pertemuan dan sebuah ballroom berkapasitas sampai 500 orang. Kehadiran Hotel Savero Depok di harapkan dapat mengakomodir kebutuhan MICE di kota Depok.

\subsection{Pengertian Quality Function Deployment}

Metodologi dalam proses perancangan dan pengembangan produk atau layanan yang mampu mengintegrasikan 'suara-suara konsumen' ke dalam proses perancangannya (Riyanto, 2006). Berikut ini dikemukakan beberapa definisi Quality Function Deployment menurut para pakar:

1.QFD adalah metode terstruktur yang digunakan dalam proses perencanaaan dan pengembangan produk untuk menetapkan spesifikasi kebutuhan dan keinginan konsumen, serta mengevaluasi suatu produk dalam memenuhi kebutuhan dan keinginan konsumen (Hasanah, 2007).

2.Quality Function Deployment (QFD) adalah sebuah sistem pengembangan produk yang dimulai dari merancang produk, proses manufaktur, sampai produk tersebut ke tangan konsumen, dimana pengembangan produk berdasarkan keinginan konsumen (Djati, 2003).

Jadi menurut teori diatas QFD adalah suatu jalan bagi perusahaan untuk mengidentifikasi dan memenuhi kebutuhan serta keinginan konsumen terhadap produk atau jasa yang dihasilkannya.

\subsection{Kerangka Pemikiran}

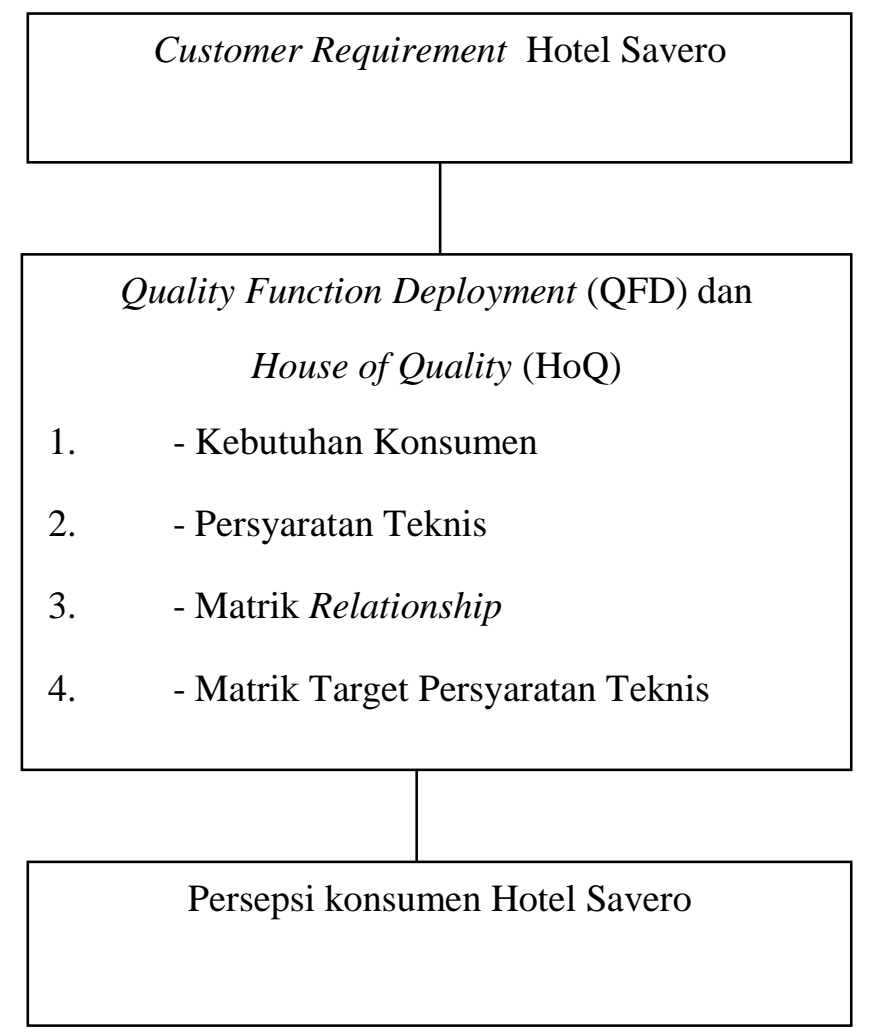

Gambar 1. Kerangka Pemikiran, Sumber: Data diolah, 2020 


\section{Metode Penelitian}

Pada penelitian ini dilakukan penyebaran kuesioner untuk seluruh tamu yang pernah menginap di Hotel Savero dalam kurun waktu 6 bulan. Peneliti menggunakan judgmental sampling, yaitu pengambilan sampel yang dilakukan dengan sengaja untuk mencapai maksud tertentu (Subiyanto, 2009). Judgmental Sampling juga disebut Purposive Sampling, pengambilan sampel berdasarkan penilaian (judgment) peneliti mengenai siapa-siapa saja yang memenuhi persyaratan untuk dijadikan sampel (Furqan, 2012). Data yang terkumpul baik primer maupun sekunder diolah melalui tahap-tahap sebagai berikut :

\section{a) Analisis Customer Requirements}

Kebutuhan pelanggan atau customer requirements merupakan pendapat pelanggan tentang karakteristik yang disyaratkan atau dibutuhkan oleh pelanggan pada Hotel Savero. Persyaratan atau kebutuhan pelanggan mengenai keinginan atau hal-hal yang diperhatikan pelanggan dalam menilai sebuah hotel dapat menggunakan analisa QFD. Dalam menyusun daftar matriks WHATs dilakukan seleksi sejumlah customer needs dengan memperhatikan kesenjangan (gap) kepuasan pelayanan. Jika terdapat gap bernilai negatif pada atribut karakteristik hotel bintang tiga yang bersangkutan maka atribut tersebut dimasukkan dalam customer needs. Jika atribut layanan mempunyai gap bernilai positif atau bernilai nol, maka tidak ada permasalahan terhadap bentuk karakteristik hotel bintang tiga tersebut. Kemudian disusun menggunakan skalalikert.

b) Analisis Tingkat Kepentingan (TKe)

Analisis ini merupakan tindak lanjut dari Customer Requirements yang bertujua nuntuk mengetahui tingkat kepentingan pelanggan terhadap pelayanan yang diberikan Hotel Savero. Dari hasil kuesioner yang diberikan kepada responden, kemudian data diolahdengan Program SPSS untuk mengambil mean mengenai tingkat kepentingan (TKe) dari atribut-atribut tersebut.

\section{c) Analisis Technical Requirements}

Analisis ini bertujuan untuk mencari tahu apa yang akan dilakukan pihak hotel, dalam hal ini hotel Savero terhadap permintaan pelanggan.

\section{d) Analisis Technical Requirement Score}

Analisis ini bertujuan untuk mengetahui Technical Requirements yang palingpenting dan memerlukan lebih banyak perhatian untuk ditindak lanjuti. Technical Requirement Score diperoleh dengan memberikan skor $9=$ kuat, $3=$ sedang, dan $1=$ lemah pada kolom hubungan antara Customer Requirements denganTechnical Requirements sehingga diketahui Technical Requirements yang paling penting dan perlu perhatian lebih untuk ditindak lanjuti. Untuk tiap elemen dalam matriks kebutuhan pelanggan akan dicari solusi atau rekayasa teknisnya. Tetapi perlu diketahui seberapa jauh technical descriptor dalam menangani dan mengendalikan kebutuhan konsumen.

\section{e) Analisis Customer Requirement Score}

Analisis Customer Requirement Score bertujuan untuk mengetahui atribut yangdianggap penting untuk perencanaan dan perubahan pelayanan di Hotel Savero. Semakin tinggi Customer Requirement Score maka atribut tersebut semakin penting dan semakin butuh prioritas utama untuk perbaikan selanjutnya.Customer Requirement Score dapat dihitung dengan melihat total skor dari Technical Requirement Score x Tingkat Kepentingan (TKe) pada setiap atribut Customer Requirements.

\section{Pembahasan}

\subsection{Quality Function Deployment dan House of Quality}

Setelah melakukan penyebaran kuesioner di Hotel Savero kemudian penulis melakukan uji menggunakan Quality Function Deployment dan House of Quality. 


\begin{tabular}{|c|c|c|c|c|c|c|c|c|c|c|c|}
\hline & & 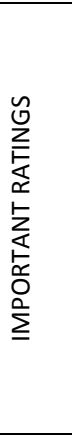 & 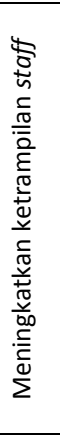 & 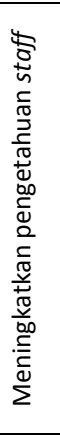 & 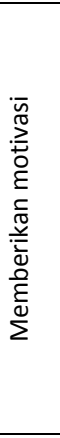 & 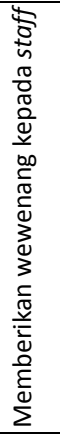 & 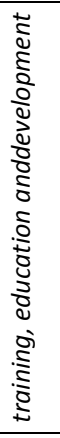 & 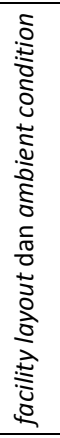 & 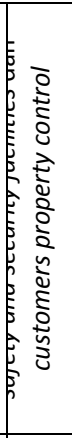 & 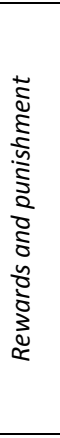 & 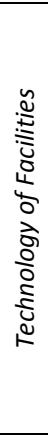 \\
\hline \multicolumn{2}{|r|}{ CUSTOMER REQUIREMENTS } & & $-r$ & $\sim$ & $m$ & $\sigma$ & in & 6 & $\wedge$ & $\infty$ & $\sigma$ \\
\hline 1 & Pelayanan sesuai yang dijanjikan & 4,35 & 9 & 3 & 1 & & 9 & 1 & & 3 & 3 \\
\hline 2 & $\begin{array}{l}\text { Proses check in dan check out yang } \\
\text { cepat }\end{array}$ & 4,15 & 9 & 9 & 1 & & 9 & 1 & & 3 & 9 \\
\hline 3 & $\begin{array}{l}\text { Proses check in dan check out yang } \\
\text { tepat }\end{array}$ & 4,16 & 9 & 9 & 1 & & 9 & 1 & & 3 & 9 \\
\hline 4 & $\begin{array}{l}\text { Staff hotel selalu bersedia membantu } \\
\text { konsumen }\end{array}$ & 4,19 & 9 & 3 & 3 & & 9 & & & 9 & \\
\hline 5 & $\begin{array}{l}\text { Staff hotel memberikan solusi yang } \\
\text { cepat untuk keluhan }\end{array}$ & 4,24 & 9 & 9 & 3 & 9 & 9 & & & 9 & \\
\hline 6 & $\begin{array}{l}\text { Staff hotel memberikan solusi yang } \\
\text { tepat untuk keluhan }\end{array}$ & 4,31 & 9 & 9 & 3 & 3 & 9 & & & 9 & \\
\hline 7 & $\begin{array}{l}\text { Staff hotel mampu memberikan rasa } \\
\text { aman bagi konsumen }\end{array}$ & 4,37 & 3 & 3 & 9 & 3 & 9 & 3 & 9 & 3 & 3 \\
\hline 8 & $\begin{array}{l}\text { Konsumen merasa nyaman selama } \\
\text { tinggal di hotel }\end{array}$ & 4,37 & 3 & 3 & 9 & 3 & 9 & 9 & 3 & 3 & 3 \\
\hline 9 & $\begin{array}{l}\text { Layanan hotel yang disediakan } \\
\text { mempunyai harga yang terjangkau }\end{array}$ & 4,27 & & & & & & 3 & & & 3 \\
\hline 10 & $\begin{array}{l}\text { Staff hotel memiliki kemampuan untuk } \\
\text { menjawab pertanyaan konsumen }\end{array}$ & 4,05 & 3 & 9 & 3 & 9 & 9 & & & 3 & \\
\hline 11 & Staff hotel memiliki keterampilan & 3,93 & 9 & 9 & 9 & 9 & 9 & & & 9 & \\
\hline 12 & $\begin{array}{l}\text { Konsumen mendapat perhatian } \\
\text { individu dari hotel }\end{array}$ & 4,39 & 9 & 3 & 1 & & 9 & & & 9 & \\
\hline 13 & $\begin{array}{l}\text { Kemauan staff untuk selalu melayan } \\
\text { dengan senyum, sapa, dan salam } \\
\text { kepada konsumen }\end{array}$ & 4,23 & 9 & 3 & 9 & 3 & 9 & & & 9 & \\
\hline 14 & $\begin{array}{l}\text { Staff hotel memperhatikan kebutuhan } \\
\text { spesifik dari konsumen }\end{array}$ & 3,85 & 3 & 1 & 1 & 3 & 9 & & & 9 & \\
\hline 15 & Ukuran kamar yang besar & 3,95 & & & & & & 9 & & & 3 \\
\hline 16 & Kamar mandi dalam kamar yang bersih & 4,59 & & & & & & 9 & & & 3 \\
\hline 17 & Tempat tidur yang nyaman & 4,49 & & & & & & 9 & 3 & & 3 \\
\hline 18 & Adanya fasilitas kolam renang & 3,85 & & & & & & 9 & & & 3 \\
\hline 19 & Adanya fasilitas TV LED dalam kamar & 4,17 & & & & & & 9 & & & 9 \\
\hline
\end{tabular}




\begin{tabular}{|c|c|c|c|c|c|c|c|c|c|c|c|}
\hline 20 & Tempat parkir yang luas & 4,21 & & & & & & 9 & & & 3 \\
\hline 21 & $\begin{array}{l}\text { Adanya fasilitas water heater dalam } \\
\text { kamar }\end{array}$ & 4,51 & & & & & & 9 & 3 & & 9 \\
\hline 22 & Adanya fasilitas restoran & 4,27 & & & & & & 9 & & & 1 \\
\hline 23 & Adanya fasilitas connecting room & 3,74 & & & & & & 9 & & & 3 \\
\hline 24 & Adanya fasilitas shuttle tengah kota & 3,87 & & & & & & 9 & & & 3 \\
\hline 25 & Adanya fasilitas telepon dalam kamar & 4,08 & & & & & & 9 & 3 & & 9 \\
\hline 26 & $\begin{array}{l}\text { Fasilitas stop kontak listrik di dalam } \\
\text { kamar yang memadai }\end{array}$ & 4,53 & & & & & & 9 & 9 & & 3 \\
\hline 27 & $\begin{array}{l}\text { Hotel mempunyai ukuran kamar yang } \\
\text { bervariasi }\end{array}$ & 4,05 & & & & & & 9 & 3 & & \\
\hline 28 & Hotel mempunyai interior yang bagus & 4,19 & & & & & & 9 & 3 & & 9 \\
\hline 29 & Hotel mempunyai eksterior yang bagus & 4,15 & & & & & & 9 & 1 & & 9 \\
\hline 30 & Adanya security 24 jam & 4,66 & 3 & & 1 & & 9 & & 9 & 3 & \\
\hline 31 & $\begin{array}{l}\text { Hotel mempunyai ameneties yang } \\
\text { lengkap (shampoo, sabun, sikat gigi, } \\
\text { dII) di dalam kamar }\end{array}$ & 4,54 & & & & & & 9 & 3 & & 1 \\
\hline & Total & & 406 & 305 & 228 & 174 & 533 & 683 & 217 & 353 & 426 \\
\hline & PRIORITAS & & 4 & 6 & 7 & 9 & 2 & 1 & 8 & 5 & 3 \\
\hline
\end{tabular}

Tabel 2 Quality Function Deployment dan House of Quality, Sumber: Data diolah, 2020

Langkah yang pertama kali harus dilakukan adalah mengumpulkan pendapat konsumen mengenai kebutuhan konsumen (Customer Requirements). Keseluruhan atribut dalam tabel Customer Requirements yang berjumlah 31 atribut adalah merupakan jawaban dari kebutuhan konsumen (Customer Requirements) yang didapat.

Tindak lanjut dari Customer Requirements adalah analisa tingkat kepentingan dengan tujuan untuk mengetahui seberapa penting atribut-atribut dari penelitian ini bagi konsumen dengan melihat nilai rata-rata yang diperoleh dari hasil skala likert kuesioner harapan konsumen selengkapnya dapat dilihat pada tabel 2.

Hasil Mean Harapan Konsumen. Setelah mengetahui tingkat kepentingan selanjutnya menentukan Technical Charateristics. Technical charateristics ini dilakukan oleh pihak hotel untuk melakukan tindakan perbaikan sesuai dengan Customer Requirements yang didapat.

Contoh dari Technical Charateristics yang dilakukan pihak hotel adalah meningkatkan keterampilanstaff. Setelah mengetahui Customer Requirements dan Technical Charateristics, maka langkah selanjutnya adalah mencari hubungan dari Customer Requirements dan Technical Requirements yaitu hubungan antara kebutuhan konsumen dengan usaha-usaha dari pihak hotel untuk mewujudkannya.

Hubungan yang terjadi sangat mungkin lebih dari satu karena setiap Customer Requirements mungkin punya hubungan lebih dari satu terhadap Technical Requirements, begitu pula sebaliknya. Hubungan yang terjadi antara Customer Requirements dan Technical Requirements dinilai dengan kategori hubungan bernilai 9 bila hubungan tersebut kuat, ini berarti bahwa Technical Characteristics menjawab Customer Requirements, hubungan bernilai 3 bila hubungan tersebut 
medium, ini berarti bahwa Technical Characteristics mendukung Customer Requirements, hubungan bernilai 1 bila hubungan tersebut lemah, ini berarti bahwa Technical Characteristics mempengaruhi Customer Requirements dan kotak kosong bila tidak ada hubungan antara Technical Characteristics dengan Customer Requirements.

Contohnya, atribut 'meningkatkan keterampilan staf', mempunyai hubungan dengan atribut proses checkin dan check out yang cepat bernilai 9 yang berarti memiliki hubungan yang kuat. Penentuan nilai hubungan antara Customer Requirements dan Technical Characteristics, merupakan kesepakatan antara peneliti dengan pihak operational hotel.

Langkah selanjutnya menentukan Customer Requirement Score.Customer Requirement Score ini didapat dengan mengkalikan Important Ratings dengan hubungan Customer Requirements dan Technical Characteristics. Contohnya Customer Requirement Score atribut 'meningkatkan keterampilan staf'. Dari perhitungan Customer Requirement Score dapat diketahui atribut Technical Characteristics apa yang menjadi prioritas pertama untuk perbaikan. Contohnya atribut 'facility layout and ambient condition' menjadi prioritas pertama selanjutnya atribut 'training education and development' menjadi prioritas kedua dan disusul atribut yang lainnya.

\subsection{Gap Tingkat Harapan dan Persepsi Konsumen}

Gap tingkat harapan dan persepsi konsumen ini dilakukan untuk mengukur kesenjangan antara harapan dan persepsi konsumen terhadap layanan yang diberikan. Pengolahan data untuk mengukur gap tingkat harapan dan persepsi konsumen ini dilakukan dengan cara mengurangkan skor rata-rata terbobot untuk persepsi konsumen terhadap layanan Hotel Savero dengan harapan konsumen sehingga diketahui ada atau tidaknya perbedaan antara harapan dan persepsi konsumen.

Hasil pengolahan dan pengujian gap tingkat harapan dan persepsi konsumen untuk tiap dimensi kualitas jasa adalah sebagai berikut:

\begin{tabular}{|l|l|l|l|l|}
\hline No & Pernyataan & Ekspektasi & Persepsi & Gap \\
\hline 1 & Pelayanan sesuai yang dijanjikan & 4,35 & 4,43 & 0,08 \\
\hline 2 & Proses check in dan check out yang cepat & 4,15 & 3,95 & $-0,2$ \\
\hline 3 & Proses check in dan check out yang tepat & 4,16 & 4,12 & $-0,04$ \\
\hline 4 & Staff hotel selalu bersedia membantu konsumen & 4,19 & 4,3 & 0,11 \\
\hline 5 & $\begin{array}{l}\text { Staff hotel memberikan solusi yang cepat untuk } \\
\text { keluhan }\end{array}$ & 4,24 & 4,27 & 0,03 \\
\hline 6 & $\begin{array}{l}\text { Staff hotel memberikan solusi yang tepat untuk } \\
\text { keluhan }\end{array}$ & 4,31 & 4,26 & $-0,05$ \\
\hline 7 & $\begin{array}{l}\text { Staff hotel mampu memberikan rasa aman bagi } \\
\text { konsumen }\end{array}$ & 4,37 & 4,37 & 0 \\
\hline 8 & $\begin{array}{l}\text { Konsumen merasa nyaman selama tinggal di } \\
\text { hotel }\end{array}$ & 4,37 & 4,45 & 0,08 \\
\hline 9 & $\begin{array}{l}\text { Layanan hotel yang disediakan mempunyai harga } \\
\text { yang terjangkau }\end{array}$ & 4,27 & 4,22 & $-0,05$ \\
\hline 10 & $\begin{array}{l}\text { Staff hotel memiliki kemampuan untuk } \\
\text { menjawab pertanyaan konsumen }\end{array}$ & 4,05 & 4,1 & 0,05 \\
\hline 11 & \begin{tabular}{l} 
Staff hotel memiliki keterampilan \\
\hline
\end{tabular} & 3,93 & 4,31 & 0,38 \\
\hline
\end{tabular}




\begin{tabular}{|c|l|l|l|l|}
\hline 12 & $\begin{array}{l}\text { Konsumen mendapat perhatian individu dari } \\
\text { hotel }\end{array}$ & 4,39 & 4,25 & $-0,14$ \\
\hline 13 & $\begin{array}{l}\text { Kemauan staff untuk selalu melayan dengan } \\
\text { senyum, sapa, dan salam kepada konsumen }\end{array}$ & 4,23 & 4,3 & 0,07 \\
\hline 14 & $\begin{array}{l}\text { Staff hotel memperhatikan kebutuhan spesifik } \\
\text { dari konsumen }\end{array}$ & 3,85 & 4,37 & 0,52 \\
\hline 15 & Ukuran kamar yang besar & 3,95 & 4,13 & 0,18 \\
\hline 16 & Kamar mandi dalam kamar yang bersih & 4,59 & 4,63 & 0,04 \\
\hline 17 & Tempat tidur yang nyaman & 4,49 & 4,53 & 0,04 \\
\hline 18 & Adanya fasilitas kolam renang & 3,85 & 1,45 & $-2,4$ \\
\hline 19 & Adanya fasilitas TV LED dalam kamar & 4,17 & 4,17 & 0 \\
\hline 20 & Tempat parkir yang luas & 4,21 & 1,86 & $-2,35$ \\
\hline 21 & Adanya fasilitas water heater dalam kamar & 4,51 & 4,57 & 0,06 \\
\hline 22 & Adanya fasilitas restoran & 4,27 & 4,17 & $-0,1$ \\
\hline 23 & Adanya fasilitas connecting room & 3,74 & 2,27 & $-1,47$ \\
\hline 24 & Adanya fasilitas shuttle tengah kota & 3,87 & 4,31 & 0,44 \\
\hline 25 & Adanya fasilitas telepon dalam kamar & 4,08 & 4,4 & 0,32 \\
\hline 26 & $\begin{array}{l}\text { Fasilitas stop kontak listrik di dalam kamar yang } \\
\text { memadai }\end{array}$ & 4,53 & 4,57 & 0,04 \\
\hline 27 & Hotel mempunyai ukuran kamar yang bervariasi & 4,05 & 4,33 & 0,28 \\
\hline 28 & Hotel mempunyai interior yang bagus & 4,19 & 4,27 & 0,08 \\
\hline 29 & Hotel mempunyai eksterior yang bagus & 4,15 & 4,09 & $-0,06$ \\
\hline 30 & Adanya security 24 jam & 4,66 & 3,03 & $-1,63$ \\
\hline 31 & $\begin{array}{l}\text { Hotel mempunyai ameneties yang lengkap } \\
\text { (shampoo, sabun, sikat gigi, dll) di dalam kamar }\end{array}$ & 4,54 & 4,56 & 0,02 \\
\hline & Tabel 3.Gap Tingkat Harapan dan Pessepsi Kons & & & \\
\hline
\end{tabular}

Tabel 3.Gap Tingkat Harapan dan Persepsi Konsumen, Sumber: Data diolah, 2020

Berdasarkan hasil Tabel 3, terlihat adanya perbedaan yang signifikan untuk proses check in dan check out yang cepat sebesar $-0,20$, proses check in dan check out yang tepat sebesar - 0,04 , staff hotel memberikan solusi yang tepat untuk keluhan sebesar $-0,05$, layanan hotel yang disediakan mempunyai harga yang terjangkau sebesar $-0,05$, konsumen mendapat perhatian individu dari hotel $-0,14$, adanya fasilitas kolam renang (pool) sebesar -2,40, tempat parkir yang luas sebesar $-2,35$, adanya fasilitas restoran sebesar -0,10, Adanya fasilitas connecting roomsebesar $-1,47$, hotel mempunyai eksterior yang bagus sebesar $-0,06$ dan adanya security 24 jam sebesar $-1,63$. Gap tertinggi pada adanya fasilitas kolam renang ( $\mathrm{pool}$ ).

Secara keseluruhan Hotel Saverobelum dapat memahami sepenuhnya apa yang konsumen harapkan, ini berarti pihak manajemen harus terus berupaya untuk dapat memahami dengan baik mengenai kebutuhan konsumen terhadap layanan yang diberikan, dengan mengumpulkan informasi yang detail tentang kebutuhan konsumen 


\section{Kesimpulan dan Saran}

\subsection{Kesimpulan}

Dari analisis kebutuhan konsumen, ternyata kualitas pelayanan yang terdapat di Hotel Savero masih belum dapat memenuhi keinginan konsumen atau belum optimal, hal ini terlihat dari masih terdapat gap pada proses check in dan check out yang cepat sebesar -0,20, proses check in dan check out yang tepat sebesar - 0,04 , staff hotel memberikan solusi yang tepat untuk keluhan sebesar $-0,05$, layanan hotel yang disediakan mempunyai harga yang terjangkau sebesar $-0,05$, konsumen mendapat perhatian individu dari hotel $-0,14$, adanya fasilitas kolam renang ( $\mathrm{pool}$ ) sebesar $-2,40$, tempat parkir yang luas sebesar -2,35, adanya fasilitas restoran sebesar -0,13, Adanya fasilitas connecting room sebesar $-1,47$, hotel mempunyai eksterior yang bagus sebesar $-0,06$ dan adanya security 24 jam sebesar $-1,63$.

\subsection{Saran}

Sebaiknya dilakukan dengan memprioritaskan pada tangible. Namun tanpa mengabaikan dimensi kualitas yang lainnya yaitu reliability, responsiveness, assurancedan empathy. Hal ini didasari pada hasil penilaian kepuasan konsumen, diketahui bahwa dimensi reliability dan tangible mendapat nilai kepuasan rendah sehingga dimensi-dimensi ini memerlukan perhatian lebih untuk diperbaiki dan ditingkatkan.

Perbaikan pada dimensi reliability sebaiknya dilakukan terutama pada atribut proses check in dan check out cepat yang dapat ditindaklanjuti oleh pihak operasional Hotel Saverodengan cara memberikan pelatihan tambahan kepada staff yang bertugas dan menggunakan sistem reservasi berteknologi canggih sehingga dapat meningkatkan kecepatan proses check in dan check out.

\section{Referensi}

Bramson, A. (2004). Quality Function Deployment: Making it, Enjoy it. New York: Workman Publishing Company.

Djati, S. (2003). Pengertian quality function deployment. Retrieved Februari 03, 2003, from http://www.wordpress.com.

Fanani, Z. (2008). Empat proses utama quality function deployment. Retrieved September 03, 2008, from http://ejurnal.undip.ac.id.

Hartanto, D. (2008). Quality systems handbook. Surabaya: PT. Indeks Gramedia.

Hasanah, T. (2007). Pengertian quality function deployment. Retrieved Agustus 01, 2007, from http://www.wordpress.com.

Sholeh, A. (2013). Info hotel baru di Surabaya. Retrieved April 20, 2013, 